\title{
Adherence to the medication regimen before and after a therapeutic awareness-raising intervention
}

Adesão ao regime medicamentoso antes e após intervenção de sensibilização terapêutica Adhesión al régimen de medicamentos antes y después de la intervención de sensibilización terapéutica Abel José Charneco Martins*; Jacinta Pires Martins**; Susana Alexandra Sevivas dos Santos***

\section{Abstract}

Background: Non-adherence to the medication regimen is currently a relevant problem that affects many of the people who need to take prescribed medication.

Objective: To describe the adherence to the oral medication regimen in a rural parish in the municipality of Chaves.

Method: Observational, descriptive, correlational, and longitudinal study using a nonprobability convenience sample of 228 individuals. Data were collected using a sociodemographic characterization form and a measure of therapeutic adherence.

Results: The level of adherence to the medication regimen increased in the second moment, after the intervention: the mean was $5.14 \pm 0.74$ in the first moment and $5.69 \pm 0.36$ in the second moment. Only $16.9 \%$ of the individuals adhered completely to the medication regimen.

Conclusion: The health care team, namely the nurse, together with the patient and the family, can outline strategies to promote the adherence to the medication regimen at the educational, behavioral, and motivational levels.

Keywords: nursing; medication adherence; health education

\section{Resumo}

Enquadramento: A não adesão ao regime medicamentoso constitui na atualidade, uma problemática pertinente que afeta grande parte das pessoas que necessitam tomar medicamentos prescritos.

Objetivos: Descrever a adesão ao regime medicamentoso por via oral dos indivíduos residentes numa freguesia rural do concelho de Chaves.

Metodologia: Estudo observacional, descritivo, correlacional, longitudinal, amostra por conveniência, náo-probabilística de 228 indivíduos. Para a recolha de dados recorreu-se a um formulário de caracterização sociodemográfica e teste de medida de adesão terapêutica. Resultados: Verificou-se que o nível de adesão ao regime medicamentoso aumentou no segundo momento, após a nossa intervenção, sendo que a média, no primeiro momento, foi de $5,14 \pm 0,74$ e no segundo momento foi de $5,69 \pm 0,36$. Apenas $16,9 \%$ dos indivíduos apresentaram adesão total ao regime medicamentoso.

Conclusáo: A equipa de saúde, nomeadamente o enfermeiro, envolvendo a pessoa e a família, poderá delinear estratégias que promovam a adesão ao regime medicamentoso, a todos os níveis: educacional, comportamental e motivacional.

Palavras-Chave: enfermagem; adesão à medicação; educação para a saúde

*MSc., Adjunct Professor, Escola Superior de Enfermagem Dr. José Timóteo Montalvão Machado, 5400-673, Chaves, Portugal [abelm@esechaves.pt]. Contribution to the article: data collection; article writing and data statistical treatment. Address for correspondence: Bairro da Traslar, Rua Sr. ${ }^{\mathrm{a}}$ da Lapa, vivenda n ${ }^{\circ} 58$, Chaves, Portugal.

Bairro da Traslar, Rua Sr. ${ }^{\mathrm{a}}$ da Lapa, vivenda ${ }^{0}$ 58, Chaves, Portugal.
**MSc., Adjunct Professor, Escola Superior de Enfermagem Dr. José Timóteo Montalvão Machado de Chaves, 5400-673, Chaves, Portugal [jmartins@esechaves.pt]. Contribution to the article: data collection; article revision and correction.

***:MSc., 1st Triennium Assistant, Escola Superior de Enfermagem Dr. José Timóteo Montalvão Machado de Chaves, 5400-673, Chaves, Portugal [ssantos@ esechaves.pt]. Contribution to the article: data collection; article revision and correction.

\section{Resumen}

Marco contextual: La no adhesión al régimen de medicamentos constituye en la actualidad una problemática pertinente que afecta a gran parte de las personas que necesitan tomar medicamentos prescritos.

Objetivos: Describir la adhesión al régimen de medicamentos por vía oral de los individuos que residen en una pedanía rural del municipio de Chaves.

Metodología: Estudio observacional, descriptivo, correlacional, longitudinal, muestra por conveniencia, no probabilística de 228 individuos. Para la recogida de datos se recurrió a un formulario de caracterización sociodemográfica y a una prueba de medida de adhesión terapéutica.

Resultados: Se comprobó que el nivel de adhesión al régimen de medicamentos aumentó en el segundo momento, después de nuestra intervención, con una media en el primer momento de 5,14 $\pm 0,74$ y en el segundo momento de 5,69 $\pm 0,36$. Solo el $16,9 \%$ de los individuos presentó adhesión total al régimen de medicamentos.

Conclusión: El equipo de salud, especialmente el enfermero, involucrando a la persona y a la familia, podrá delinear estrategias que promuevan la adhesión al régimen de medicamentos, a todos los niveles: educativo, del comportamiento y motivacional.

Palabras clave: enfermería; cumplimiento de la medicación; educación en salud 


\section{Introduction}

Life expectancy at birth has been increasing in many countries worldwide with a relevant impact on the social, economic, and health levels. In recent decades, population aging has accelerated in Portugal, particularly in the northern region, where the population has a mean age of 80.1 years (Administração Regional de Saúde, 2012). In fact, age progression leads to an increase in the coexistence of multiple diseases and associated polypharmacy, which makes individuals more vulnerable to adverse physiological interactions and reactions that require health professionals to deliver special and individualized care (Soares, 2009). Given the high prevalence of symptomatic diseases in individuals over 65 years of age, this age group consumes approximately $25 \%$ of the total sales of prescribed and non-prescribed drugs, a percentage which is expected to reach about $40 \%$ by 2030 (Ribeiro, 2014). In light of this situation, it is essential, on the one hand, to classify/rationalize medicines while promoting adherence, and, on the other hand, to implement non-pharmacological therapeutic options, such as adequate nutrition and physical activity. According to Henriques (2011, p. 140), "Adherence to medication and therapeutic regimes continues to be a current issue due to its negative impact on older people, professionals, and healthcare systems".

Patients should be able to identify their medications by name or visual appearance, the therapeutic action and side effects of medications, the instructions for safe medication, use reminders, store medicines properly, and learn how to take them properly so that they are able to effectively manage their medication regimen and, consequently, increase medication adherence (Henriques, 2011).

Among the physiological changes that occur over the years which have an impact on the intake, absorption, distribution, metabolism, and elimination of drugs, the following should be highlighted: decreased body water, decreased muscle mass, increased fat tissue, decreased serum albumin levels, kidney weight loss, and reduced liver blood flow (Ribeiro, 2014). Although these processes are not linear, given the heterogeneity and uniqueness of aging, they significantly affect the entire medication process. In view of the above, all of those involved in the therapeutic process, namely health professionals, should be aware of these processes and be proactive in their practice.

Therefore, the purpose of this study is to describe the adherence to the oral medication regimen of individuals living in a rural parish in the municipality of Chaves with a view to providing useful indicators for the assessment of nursing interventions aimed to increase the adherence to the oral medication regimen in the community.

\section{Background}

Adherence to the medication regimen is today an important area of attention in nursing practice and a priority area in health (Conselho Internacional de Enfermeiros, 2011). As a concept, adherence to the medication regimen is a focus of nursing attention that is defined as a

Status: Self-initiated action to promote wellness, recovery and rehabilitation, following directions without deviation, devoted to a set of actions or behaviors. Compliant with treatment regimen, taking medicine as instructed, behavior change for the better, signs of healing, collection of medicine on due date, internalization of the value of health care behavior and obeying instructions regarding treatment. (Often associated with support from family and significant others, knowledge about supplied drugs and the disease process, client motivation, client health worker relationship.). (Conselho Internacional de Enfermeiros, 2011, p. 38)

Adherence to the medication regimen is achieved through the compliance and agreement with what is recommended, which translates into the person's action and behavior concerning the intake of prescribed medication and the therapeutic indications provided by health professionals (World Health Organization, 2003).

Aging and the loss of physical abilities con- 
tribute to the development of most chronic diseases and trigger a vicious cycle between chronic diseases, functional disability, and physical and mental impairment. Most researchers working on issues related to aging, particularly a successful aging, argue that older people should stay in their own environment and community and that policies should be devised to support and help them (Paúl, 2005). Based on this perspective, we, as a higher education institution, provide services to the community, in response to article 4(I) of Law No. 38/2007 of $16 \mathrm{Au}-$ gust. In turning toward the community, we seek, within our power, to become closer to the geographically distant community, since, within the heath team, and due to their professional responsibilities and close relationship with the patient, nurses are the most well-positioned professionals to support, advice, guide, educate, inform, instruct, and train, thus becoming a point of contact for the patient (Davies, 2010).

Patients believe that nurses' availability to listen and help people individually and continuously is very useful for them to manage their disease, which may contribute to increasing adherence to the therapeutic regimen (Henriques, 2011).

\section{Research question}

What is the level of adherence to the oral medication regimen of individuals living in a rural parish in the municipality of Chaves?

\section{Methodology}

This study was developed in a rural community and results from the joint project Saúde na Comunidade (Health in the Community), which started in 2011, between the Escola de Enfermagem Dr. José Timóteo Montalvão Machado (ESEDJTMM) (through its teachers/nurses and nursing students), the City Hall of Chaves (provision of the Mobile Health Unit), and the Parish Council of S. Pedro de Agostém (allocation of resources). This partnership aims at the development of health education initiatives and the provision of health care based on solidarity to the rural communities, with the purpose of promoting health and mitigating the effects of the populations' geographic remoteness and the poor access to health care services. Therefore, this observational, longitudinal, descriptive-correlational study was conducted over a period of 8 months with two moments for data collection (at the beginning and end of the process) and an in-between phase for health education and promotion through monthly nursing initiatives, which were carried out individually using active teaching methodologies through counselling, education, instruction, and training.

\section{Population and sample}

After the president of the Parish Council had raised the population's awareness, all individuals who attended our Mobile Health Unit were initially assessed. The study included all individuals aged over 18 years who were able to answer the form and showed interest in participating voluntarily $(n=228)$. Thus, a nonprobability convenience sample was selected based on the easy access to the participants, without any criteria for inclusion or exclusion besides being part of the resident population (Bianchi, 2002).

\section{Instruments}

A form was designed for collecting the following information: (i) sociodemographic characteristics (age, gender, marital status, level of education, professional activity); ii) disease, current health problems, and prescribed medication. To assess the level of adherence to the medication regimen, the instrument Medida de Adesão aos Tratamentos (Measure of Therapeutic Adherence - MTA) was applied. This instrument was developed and validated for the Portuguese population by Delgado and Lima (2001). It includes seven items on the following aspects: 1 . "Forgetting to take the medicines"; 2 . "Being careless with the time to take the medicines"; 3 . "Stopping treatment after improvement"; 4. "Stopping treatment, on one's own initiative, after feeling worse"; 5. "Increasing the number of medications because of feeling worse"; 
6. "Stopping treatment because medicines ran out"; 7. "Stopping treatment for any reason apart from being instructed to do so by the doctor". Each item is rated on a 6-point Likert scale, depending on the frequency of the above-mentioned circumstances, so that 1 corresponds to always and 6 to never. In addition to disaggregating, item by item, the values directly resulting from the MTA application, it is possible, by adding the values of each item and dividing the total sum by the number of items, to calculate an overall index of adherence. Based on this index and the usually accepted criterion, individuals are considered non-adherent if they obtain a score from 1 to 5 , and adherent if they obtain a score of 6 , as suggested by the authors.

\section{Procedure}

In the initial contact, participants were asked to bring their medications to the following meeting with the purpose of accurately identifying their pharmacological treatment.

In order to assess the level of adherence to the medication regimen, the MTA was applied in two different moments, with a mean interval of 8 months. The data for sample characterization were collected upon the first application of the MTA.

During the 8-month period, the research team conducted a series of monthly individualized nursing interventions on surveillance, education, information, advice, and training. For this purpose, active teaching methodologies were used, namely training in using the weekly medication organizer, which was offered to individuals who showed more difficulties in adhering to the medication regimen.

After this period, the MTA was again applied, and the results before and after the interventions were compared.

For data collection and processing purposes, the volunteers who agreed to participate in the study were asked to give their informed consent and ensured that all ethical principles would be met. Data confidentiality was ensured by assigning a number to each individual for statistical treatment and keeping their identification in separate records for subsequent health guidance.

\section{Statistical Analysis}

Data were processed using the Statistical Package for the Social Sciences (SPSS, version 20) for sample characterization (participants' personal characteristics), estimation of the statistics used in the presentation, item by item, of data on the MTA application in the first moment of research (absolute and relative frequencies), data aggregation with a view to determining the index of adherence and comparing the initial and final results, estimation of the corresponding statistics of location and dispersion (mean, mode, and standard deviation), and inferential evaluation of the significance of the differences between the sample means of the index of adherence scores resulting from the MTA application in both moments (parametric Student's t-test).

\section{Results}

Most of the 228 sampled individuals were women $(71.5 \%)$, aged between 45 and 92 years (mean 67.1; median 67; mode 72; and standard deviation 12 ). With regard to the level of education, $64.1 \%$ of them knew how to read and write, but had only attended the first cycle of basic education, and only $2.2 \%$ had completed secondary education. Most participants (61.3\%) were retired; $198(87 \%)$ reported taking only the prescribed drugs.

With regard to the diseases diagnosed by a physician, the most reported ones were cholesterolemia, 104 individuals (45.6\%), followed by high blood pressure (HBP), 98 individuals (43\%), diabetes, 48 individuals (21\%), cardiovascular diseases, 24 individuals $(10.5 \%)$, and, finally, cerebrovascular diseases, 20 individuals (8.8\%).

Participants who took prescribed drugs on a daily basis reported taking a mean of 3.79 medicines, median 3, standard deviation 1.97 , minimum 0 , maximum 9 .

In this study, 98 individuals (43\%) were polymedicated, taking 4 or more prescribed drugs, with a mean of 3.79 drugs/ day.

The analysis of the frequency of each MTA item showed that, in the first moment (Table 1), 60 (30\%) participants reported 
never having forgotten to take medication and $44(22 \%)$ stated that they had often forgotten to take them. Fifty-eight (29\%) participants stated that they had never been careless with the time for taking medicines and $47(23.5 \%)$ reported that they had sometimes been careless. Ninety-nine (49.5\%) participants stated that they had never stopped taking the medication because of feeling better and 34 (17\%) reported that they had sometimes stopped taking the medication for this reason; 116 (58\%) participants reported that they had never stopped taking the medication after feeling worse and $24(12 \%)$ revealed that they had sometimes stopped taking the medication for this reason. A total of 129 (64.5\%) participants reported that they had never increased the number of medicines because they felt worse and $23(11.5 \%)$ reported that they had sometimes taken one or more medicines after feeling worse. With regard to interrupting the treatment because they had run out of medicines, 95 (47.5\%) participants stated that it had never happened and $17(8.5 \%)$ reported that they had often interrupted it. A total of $144(72 \%)$ individuals reported that they had never stopped taking the medication any reason apart from being instructed to do so by the doctor, and $3(1.5 \%)$ participants said that they had often done it.

Table 1

Adherence to the medication regimen in the first moment

\begin{tabular}{|c|c|c|c|c|c|c|c|c|c|c|c|c|}
\hline \multirow{2}{*}{ Measure of Therapeutic Adherence } & \multicolumn{2}{|c|}{ Always } & \multicolumn{2}{|c|}{ Almost always } & \multicolumn{2}{|c|}{ Often } & \multicolumn{2}{|c|}{ Sometimes } & \multicolumn{2}{|c|}{ Rarely } & \multicolumn{2}{|c|}{ Never } \\
\hline & $\mathrm{N}$ & $\%$ & $\mathrm{~N}$ & $\%$ & $\mathrm{~N}$ & $\%$ & $\mathrm{~N}$ & $\%$ & $\mathrm{~N}$ & $\%$ & $\mathrm{~N}$ & $\%$ \\
\hline Have you ever forgotten to take your medicine? & & & 2.0 & 1.0 & 44.0 & 22.0 & 37.0 & 18.5 & 57.0 & 28.5 & 60.0 & 30.0 \\
\hline $\begin{array}{l}\text { Have you ever been careless with the time for taking } \\
\text { your medicine? }\end{array}$ & 1.0 & 0.5 & 3.0 & 1.5 & 34.0 & 17.0 & 47.0 & 23.5 & 57.0 & 28.5 & 58.0 & 29.0 \\
\hline $\begin{array}{l}\text { Have you ever stopped taking your medicine because of } \\
\text { feeling better? }\end{array}$ & 1.0 & 0.5 & 4.0 & 2.0 & 9.0 & 4.5 & 34.0 & 17.0 & 53.0 & 26.5 & 99.0 & 49.5 \\
\hline $\begin{array}{l}\text { Have you ever stopped taking your medicine because of } \\
\text { feeling worse? }\end{array}$ & & & 1.0 & 0.5 & 2.0 & 1.0 & 24.0 & 12.0 & 57.0 & 28.5 & 116.0 & 58.0 \\
\hline $\begin{array}{l}\text { Have you ever taken one or more of your medicines, on } \\
\text { your own initiative, because of feeling worse? }\end{array}$ & & & 1.0 & 0.5 & 9.0 & 4.5 & 23.0 & 11.5 & 38.0 & 19.0 & 129.0 & 64.5 \\
\hline $\begin{array}{l}\text { Have you ever interrupted the treatment because you } \\
\text { had let your medicines run out? }\end{array}$ & & & 1.0 & 0.5 & 17.0 & 8.5 & 40.0 & 20.0 & 47.0 & 23.5 & 95.0 & 47.5 \\
\hline $\begin{array}{l}\text { Have you ever stopped taking your medicines for any } \\
\text { reason apart from being instructed to do so by the } \\
\text { doctor? }\end{array}$ & & & 1.0 & 0.5 & 3.0 & 1.5 & 15.0 & 7.5 & 37.0 & 18.5 & 144.0 & 72.0 \\
\hline
\end{tabular}

At the beginning of the process, before the intervention and monitoring phase, data showed that the main reasons for being partially non-adherent to the medication regimen were forgetting to take medication, being careless with the time to take them, and stopping treatment because medicines ran out.

In the first moment, only 38 (16.9\%) participants answered never in all items, thus being considered, according to the criteria established, adherent to the regimen. Therefore, the remaining 190 participants were considered non-adherent, even though they were only partially non-adherent to the medication regimen.

In order to assess the overall adherence to the medication regimen and compare the results before and after the therapeutic awareness-raising intervention (Table 2), the data obtained in each MTA application (as mentioned in the section describing the instruments used) were aggregated to calculate an adherence index, or overall level, for each moment. The reliability of these results was assessed by estimating the instrument's internal consistency (mean correlation between the items and the adherence index) through the Cronbach's alpha coefficient. The obtained value of 0.98 strongly suggests a very good reliability (Pestana \& Gageiro, 2005).

The scores in Table 2 show that the mean score of adherence to the medication regimen was 5.14 and the median score was 5.28 in the first moment of assessment. In the second mo- 
ment, the mean score was 5.69 and the median score was 5.85. In general, participants showed a good adherence to the medication regimen, especially in the second moment. The comparison between the mean scores of adherence to the medication regimen in both moments showed an increase of 0.55 units between the first and the second moment, with a statistically significant difference $(p \leq 0.05)$, based on a significance level of $5 \%$.

Table 2

Adherence to the medication regimen before and after the intervention

\begin{tabular}{ccc}
\hline & $\begin{array}{c}\text { Adherence 1st moment } \\
\text { before the intervention }\end{array}$ & $\begin{array}{c}\text { Adherence 2nd moment after } \\
\text { the intervention }\end{array}$ \\
\hline Mean & 5.14 & 5.69 \\
Median & 5.28 & 5.85 \\
$\begin{array}{c}\text { Standard } \\
\text { deviation }\end{array}$ & 0.74 & 0.36 \\
\hline
\end{tabular}

\section{Discussion}

The sample consisted mostly of women with low education levels. These data are in line with the results found in other studies (Delgado \& Lima, 2001; Henriques, 2011), in which the samples were also mostly composed of females and individuals with the first cycle of studies.

In this sample, $45.6 \%$ of the respondents had cholesterolemia, followed by HBP (43\%) and diabetes $(21 \%)$. In this case, the results are not in line with those obtained by Henriques (2011), who found a higher incidence of diabetes (71.7\%), followed by HBP (61.5\%), and cholesterolemia (50.6\%).

Indeed, aging, associated with less healthy lifestyles, leads to an increase in the prevalence of chronic diseases, particularly cerebrovascular and cardiovascular diseases, HBP, diabetes, and cholesterolemia (Direção-Geral da Saúde, 2013).

The mean number of prescribed drugs taken by the respondents was 3.79. A similar result was found by Monterroso, Joaquim, and Sá (2015) in home care settings, in which a large percentage of individuals (41.8\%) took three to five drugs. In the study of Henriques (2011), the participants took a mean of 5.61 prescribed medications on a daily basis.

With regard to medication intake, $43 \%$ reported taking four or more types of drugs every day. These data are inferior to those obtained by Henriques (2011), who found that $72.1 \%$ of participants were polymedicated.
As to the measure of adherence, $30 \%$ of the participants reported that they had never forgotten to take their medication and $29 \%$ of the participants stated that they had never been careless with the time for taking the medicines. These scores are similar to those found by Soares (2009) and Henriques (2011), particularly on the items "Forgetting to take the medicines" and "Being careless with the time to take the medicines".

In the overall assessment of the adherence to the medication regimen, and comparing the results before and after the nursing intervention, a mean score of 5.69 was obtained in the second moment. These results are in line with those obtained by Ferreira, Graça, and Calvinho (2016), with a mean of adherence of 5.63.

The comparison of the means in both moments showed an increase of 0.55 units between the first and the second moment. This result is higher than that found by Henriques (2011), with an increase of only 0.17 units before and after the intervention.

The level of adherence to the medication regimen was, therefore, higher in the second moment, which allows assuming that the therapeutic awareness-raising intervention carried out between both moments was effective.

This study had some limitations related to the fact that the sample was selected using a convenience rather than a probability sampling technique; the reduced sample size; and the fact that adherence to the medication regimen was only assessed based on the individuals' perceptions and accounts of medication intake. 


\section{Conclusion}

The study on the adherence to the prescribed medication regimen was, along with other methods, a way of understanding how individuals living in a rural community manage their health and illness and how nurses can play a key role in helping them to adequately manage their disease.

This study allowed identifying individuals with low adherence to the medication regimen, as well as adapting the non-pharmacological therapeutic interventions, namely by increasing health education, given the expected impact of the risks of non-adherence to the therapeutic regimen associated with chronic diseases. The most relevant items for poor adherence were forgetting to take the medicines, being careless with the time to take them, and stopping treatment because medicines ran out.

In order to improve adherence, both to the medication regimen and the therapeutic regimen (in general), nurses' educational, behavioral, and motivational strategies will be more effective if directed to the patient and/ or family. These strategies should include an explanation of the disease and the importance of adopting a healthy lifestyle, enhancing the patients' motivation.

We intend to continue this study in the future by investigating other variables, namely the medication regimen complexity index, which may influence the adherence to the medication regimen, and, consequently, designing strategies for nursing intervention.

Our ultimate purpose for the health intervention at the basis of this study was continuing to improve the well-being and quality of life of the population through awareness-raising interventions that can motivate people to adopt healthier strategies, behaviors, and lifestyles to achieve health gains.

\section{References}

Administração Regional de Saúde. (2012). Perfil local de saúde 2012: ACeS Alto Tâmega e Barroso. Porto, Portugal: Autor. Retrieved from http://portal.arsnorte.min-sau-
de.pt/ARSNorte/dsp/ACES/PLS2012_1925_Alto-

TamegaBarroso.pdf

Bianchi, J. (2002). Métodos e teoria de investigação. Vila Real, Portugal: Universidade de Trás-os-Montes e Alto Douro.

Conselho Internacional de Enfermeiros. (2011). CIPE versão 2: Classificação para a prática de enfermagem. Lisboa, Portugal: Ordem dos Enfermeiros.

Davies, N. (2010). Improving self-management for patients with long-term conditions. Nursing Standard, 24(25), 49-56. doi: 10.7748/ns2010.02.24.25.49. c7562

Delgado, A. B., \& Lima, M. L. (2001). Contributo para a validação concorrente de uma medida de adesão aos tratamentos. Psicologia Saúde \& Doenças; 2(2), 81-100. Retrieved from http://www.scielo.mec.pt/ $\mathrm{pdf} / \mathrm{psd} / \mathrm{v} 2 \mathrm{n} 2 / \mathrm{v} 2 \mathrm{n} 2 \mathrm{a} 06 . \mathrm{pdf}$

Direção-Geral da Saúde. (2013). Plano Nacional de Saúde 2012-2016. Lisboa, Portugal: Autor.

Ferreira, R. S., Graça, L. C., \& Calvinho, M. L. (2016). Adesão ao regime terapêutico de pessoas com hipertensão arterial em cuidados de saúde primários. Revista de Enfermagem Referência, 4(8), 7-15. doi: 10.12707/RIV15070

Henriques, M. A. (2011). Adesão ao regime medicamentoso em idosos na comunidade: Eficácia das intervençōes de enfermagem (Doctoral thesis). Retrieved from http://hdl.handle.net/10451/3801

Monterroso, L. E., Joaquim, N., \& Sá, L. O. (2015). Adesão do regime terapêutico medicamentoso dos idosos integrados nas equipas domiciliárias de cuidados continuados. Revista de Enfermagem Referência, 4(5), 9-16. doi: 10.12707/RIV14047

Paúl, C. (2005). Envelhecimento e ambiente. In. L. Soczka (Org.), Contextos humanos e psicologia ambiental (pp. 247-268). Lisboa, Portugal: Fundação Calouste Gulbenkian.

Pestana, M., \& Gageiro, J. (2005). Análise de dados para as ciências sociais: A complementaridade do SPSS. Lisboa, Portugal: Edições Sílabo.

Soares, M. A. (2009). Avaliação da terapêutica potencialmente inapropriada no doente geriátrico (Doctoral thesis). Retrieved from http://hdl.handle. net/10451/279

Ribeiro, C. A. (2014). Farmacologia no idoso. In Geriatria fundamental: Saber e praticar (pp. 119-135). Lisboa, Portugal: Lidel, Ediçóes Técnicas.

World Health Organization. (2003). Adherence to longterm therapies: Evidence for action. Retrieved from http://www.who.int/chp/knowledge/publications/ adherence_full_report.pdf?ua=1 
